\title{
Development and Characterization of Neutralizing Antibodies Against Zaire Ebolavirus Glycoprotein and Protein $\mathbf{4 0}$
}

\author{
Dong-Shan $\mathrm{Yu}^{\mathrm{a}}$ Tian-Hao Weng ${ }^{\mathrm{a}}$ Ling Shen ${ }^{\mathrm{b}}$ Xiao-Xin $\mathrm{Wu}^{\mathrm{a}}$ Chen-Yu Hu \\ Frederick X.C. Wang ${ }^{c}$ Zhi-Gang Wu ${ }^{a}$ Hai-Bo Wu ${ }^{a}$ Nan-Ping Wu ${ }^{a}$ Lan-Juan Lia \\ Hang-Ping Yao
}

aState Key Laboratory for Diagnosis and Treatment of Infectious Diseases, Collaborative Innovation Center for Diagnosis and Treatment of Infectious Diseases, The First Affiliated Hospital, School of

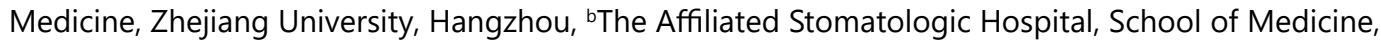
Zhejiang University, Hangzhou, China, 'Department of Bioengineering, Erik Jonsson School of Engineering and Computer Science, The University of Texas at Dallas, Dallas, USA

\section{Key Words}

Zaire Ebola virus $\cdot \mathrm{GP} \cdot \mathrm{VP} 40 \cdot \operatorname{TrVLP} \cdot$ Monoclonal antibody $\cdot$ Anti-viral effect

\begin{abstract}
Background/Aims: Monoclonal antibodies (mAbs) are presently the most promising treatment against Ebola virus disease (EVD), and cocktail of two or more antibodies likely confers protection through complementary mechanisms. Zaire Ebolavirus (EBOV) glycoprotein (GP) and viral protein 40 (VP40) are targets for designing neutralizing antibodies. Currently, the antiviral therapeutics of mAb-cocktails are still limited solely to anti-GP antibodies, there is no Abs cocktail against Zaire EBOV GP and VP40, which both have important interactions with host cellular membrane. Methods: We used hybridoma technology to produce anti-Zaire EBOV GP mAb against GP receptor binding domain, and anti-Zaire EBOV VP40 mAbs against the $\mathrm{N}$-terminal domain, the $\mathrm{C}$-terminal domain, respectively; synthesized Zaire EBOV transcription and replication competent virus like particles (trVLPs), which model even all aspects of the EBOV life cycles in order to evaluate the anti-viral effect of mAbs. Then, we characterized the anti- Zaire EBOV trVLPs effect of anti-GP and VP40 mAbs in vitro by real time-PCR, immunofluorescence assay and western blot analysis. Results: Our results demonstrate that anti-GP or anti-VP40 mAbs effectively inhibit trVLPs replication. The cocktails of anti-GP and anti-VP40 mAbs, or between anti-VP40 mAbs, had synergistic anti-trVLPs effect. Meanwhile, the detailed DNA and amino acid sequences of the mAbs were checked. Conclusion: The study verifies neutralizing efficacy of anti-GP or anti-VP40 mAb, report promising cocktail of anti-GP and anti-VP40 mAb, or cocktail of two anti-VP40 mAbs. To our knowledge, this is the first account to report the important anti-viral effect of cocktails of anti-GP and anti-VP40 $\mathrm{mAbs}$ in vitro.

D.-S. Yu, T.-H. Weng and L. Shen contributed equally to this work.

Published by S. Karger AG, Basel




\section{Cellular Physiology Cell Physiol Biochem 2018;50:1055-1067

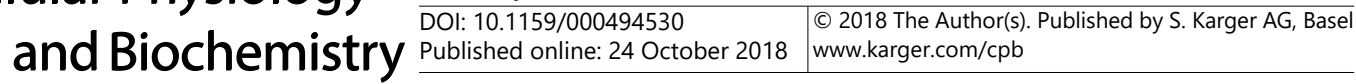 \\ Yu et al.: Synergistic Anti-EBV Effect of Mabs}

\section{Introduction}

Ebola virus (EBOV) is a single-stranded, negative-sense RNA virus which exhibits a unique heterogeneous filamentous structure, was first reported in 1976 as the cause of the highly contagious zoonotic disease, Ebola viral disease (EVD) in humans and other primates [1]. Five different species of EBOV have been characterized: 1) Zaire virus (Zaire EBOV); 2) Sudan virus (Sudan EBOV); 3) Bundibugyo virus (Bundibugyo EBOV); 4) Taï Forest virus (Taï Forest EBOV); and 5) Reston virus (Reston EBOV) [2]. The EVD epidemic in Western Africa caused by Zaire EBOV in 2013-2016 and associated to 28, 712 cases and 11, 323 deaths in 11 countries $[3,4]$, high viral transmissibility, and relatively high mortality rate has demonstrated EVD as a serious global health threat. To date, there is no effective direct acting anti-EBOV treatment.

Up to now, the current therapeutic methods for patients with suspected or confirmed EVD is limited. A few studies have examined the anti-viral effect of neutralizing Zaire EBOV antibody (Ab), and around 20 Zaire EBOV Abs have been identified and characterized [5-7]. Few of them, including the single antibody Ab114, the two-Abs cocktail MIL77E, and the 3-Abs cocktail MB-003, ZAb, and ZMapp ${ }^{\mathrm{TM}}$ were tested in non-human primate models; only $\mathrm{ZMapp}^{\mathrm{TM}}$ has reached phase II clinical trials $[5,6]$.

EBOV GP and VP40 are currently the main targets for designing antibodies. GP is composed of ectodomain GP1 and a trans-membrane fusion domain GP2. The core of GP1 is subdivided into three domains: the glycan cap, the receptor binding domain (RBD), and the mucin-like domain (MLD) $[8,9]$. The glycan cap is the outer part of GP1, which forms a chalice to protect the receptor binding sites from antibodies; the RBD sub domain is exposed to the host membrane surface, which carrying putative binding domain sites; the MLD sub domain sustains the linkage with GP2 and stabilizes the metastable pre-fusion conformation. Therefore, GP1 and GP2 orchestrate viral entry, including attachment, uptake, and fusion [10-12].

The matrix protein VP40 of EBOV is also a promising therapeutic target of interest. VP40 is the most abundantly protein in EBOV, locates beneath the viral bilayer to ensure structural integrity of the particle. There are two structures in VP40: the N-terminal domain (NTD), regulates dimerization, mediates interaction with plasma membrane for efficient VP40-plasma membrane localization; the C-terminal domain (CTD), mediates membrane binding and oligomerization [13]. Although antiviral therapeutics targeting VP40 are still underway, it's proved that inhibition of VP40 oligomerization is an effective means of halting budding, and disturbance in the loop region of VP40, would likely contribute towards the discovery of novel EBOV inhibitors [14-16].

The combination of antibodies (cocktail) has been proved for synergistic protection and becoming popular treatment methods, such as MIL77E, MB-003, and ZMapp ${ }^{\text {TM }}$ mentioned above. However, most of the Abs, including the 3-Abs cocktail ZMapp ${ }^{\mathrm{TM}}$, were designed to target different epitopes of the EBOV GP $[5,6,17]$, with limited characterization of Abs against EBOV VP40. Up to now, there is no research characterizing a neutralizing Abs cocktail against Zaire EBOV GP and VP40. Therefore, based on the fact that both GP and VP40 have vital roles in Zaire EBOV life cycle, and both have important interactions with host cellular membrane or plasma membrane, we designed and synthesized specific monoclonal antibodies (mAbs) targeting the RBD of GP and two different regions of VP40 (NTD and CTD). On a basis of ZEBOV trVLPs system, we verify the neutralizing efficacy of each anti-GP or anti-VP40 mAb, and report promising cocktail of anti-GP and anti-VP40 mAbs, or cocktail of two anti-VP40 mAbs. Here we discuss novel cocktail of antibodies-mediated neutralization of virus infectivity in vitro. 


\section{Cellular Physiology Cell Physiol Biochem 2018;50:1055-1067 \begin{tabular}{ll|l} 
and Biochemistry & Published online: 24 October 2018 & $\begin{array}{l}\text { (c) } 2018 \text { The Author(s). Published by S. Karger AG, Basel } \\
\text { www.karger.com/cpb }\end{array}$
\end{tabular}}

Yu et al.: Synergistic Anti-EBV Effect of Mabs

\section{Materials and Methods}

\section{Ethics statement}

$\mathrm{BALB} / \mathrm{c}$ mice studies for biomedical research were performed strictly according with the Institutional Guiding Principles. Informed consent (2018-543) was obtained from the Ethics Committee of the First Affiliated Hospital, School of Medicine, Zhejiang University.

\section{Design and production of $m A b s$}

Based on the amino acid sequence of GP and VP40 of Zaire Ebola virus (Gen Bank: AIE11908.1, and AJP15081.1), we designed peptides targeting fragments of GP and VP40, respectively. The peptides were selected by carrier Keyhole Limpet Hemocyanin (KLH, Sigma, St. Louis, MO, USA). Then, the peptideKLHs compounds were inoculated into BALB/c mice. Later, splenocytes derived from the immunized mice were fused with the myeloma cells Sp2/0-Ag14 in vitro to generate hybridoma cells. After cells fusion, the hybridoma cells producing antibody were screened by enzyme-linked immunoadsorbent assay (ELISA), and were subcloned three times by limited dilution. After the hybridoma cells clones were grown up in flasks, cells were harvested and injected intraperitoneally in pristane-primed BALB/c mice $\left(5 \times 10^{6}\right.$ cells/mouse). The ascites were collectd after two weeks and purified by ammonium sulphate precipitation method. The precipitation was then washed once with $45 \%$ ammonium sulphate and dissolved in least volumes of phosphate-buffered saline (PBS), dialyzed against PBS for $72 \mathrm{~h}$ with several changes. The concentrations of purified ascites were determined by Bradford method. The class and subclass of mAbs were determined by immunoType ${ }^{\mathrm{TM}}$ mouse monoclonal antibody isotyping kit (Thermo Fisher, Waltham, MA, USA, Cat\#26178) [18-20]. Following this process and primary screen, we obtained monoclonal antibodies against ZEBOV GP or VP40, which summarized in Table 1.

\section{Cell line and plasmids}

Human embryonic kidney 293T cells (ATCC, Manassas, VA, USA, Cat\#CRL-3216) were cultured in Dulbecco's modified Eagle's medium (DMEM; Thermo Fisher, Waltham, MA, USA, Cat\#10566016) containing 10\% fetal calf serum (FBS; Gibco, Waltham, MA, USA, Cat\#10099141), 2 mM L-glutamine (Life Technologies, Cat\#25030081), and 1\% penicillin- streptomycin (Life Technologies, Cat\#10378016) at $37^{\circ} \mathrm{C}$ with 5\% $\mathrm{CO}_{2}$. Plasmids p4cis-vRNA-RLuc, pCAGGS-VP30, pCAGGS-VP35, pCAGGS-NP, pCAGGS-L, pCAGGSTim1, and pCAGGS-T7 were kindly provided by Drs. Heinz Feldmann and Thomas Hoenen, Rocky Mountain Laboratories, National Institute of Health (NIH). The p4cis-vRNA-RLuc contains Zaire EBOV genes (GP1, GP2, VP40, and VP24), non-coding regions, and a reporter gene, is suitable to produce trVLPs and check reporter activity to to detect the level of virus replication.

Production of trVLPS

293T cells (p0) were transfected with plasmids encoding each Zaire EBOV structural protein and a Renilla luciferase reporter (250 ng p4cis-vRNA-RLuc, 75 ng pCAGGS-VP30, 125 ng pCAGGS-VP35, 125 ng pCAGGS-NP, 1, 000 ng pCAGGS-L, pCAGGS-T7) by transfection reagent FuGENE HD (Promega, Madison, WI, USA, Cat\#E2311) [21, 22]. Cell supernatant containing released trVLPs was harvested $72 \mathrm{~h}$ post transfection, cells and cellular debris were pelleted by gentle centrifugation at $175 \times \mathrm{g}$. The supernatant was then used to infect target 293T cells (p1) previously transfected with RNP components (75 ng pCAGGS-VP30, 125 ng pCAGGS-VP35, 125 ng pCAGGS-NP, 1, 000 ng pCAGGS-L, 250 ng pCAGGS-Tim1). Target 293T cells (p2p5) were treated in a similar manner. To get the concentrated trVLPs, the total value about $200 \mathrm{ml}$ cleared supernatant (33ml cleared supernatants in each pipe) was centrifuged at $25,000 \mathrm{rpm}$ for $3 \mathrm{~h}$ at $4{ }^{\circ} \mathrm{C}$ with a SW-28 rotor. The resulting pellet was resuspended in $100 \mu \mathrm{l}$ ice-cold NTE buffer (10 mM Tris, pH 7.5, 100 $\mathrm{mM} \mathrm{NaCl}, 1 \mathrm{mM}$ EDTA). trVLPs were left on ice until use.

Imaging of the DiI-labeled trVLPs internalization in live 293T cells

Purified trVLPs (quantified as $100 \mu \mathrm{g}$ viral protein) were suspended in $1 \mathrm{ml}$ of NTE buffer, then, 1, 1'-Dioctadecyl-3, 3,3',3'-Tetramethylindocarbocyanine Perchlorate (DiI, dissolved in ethanol, final concentration:10 $\mu \mathrm{M}$, Invitrogen, Waltham, MA, USA, Cat\# D282), was added and mixedthoroughly. The mixture was gently shaken for $1 \mathrm{~h}$ at room temperature and then filtratedthrough a filter $(0.22 \mu \mathrm{m}$ pore 


\section{Cellular Physiology Cell Physiol Biochem 2018;50:1055-1067 \begin{tabular}{l|l|l} 
and Biochemistry Published online: 24 October 2018 & $\begin{array}{l}\text { ○ } 2018 \text { The Author(s). Published by S. Karger AG, Basel } \\
\text { www.karger.com/cpb }\end{array}$ \\
\hline
\end{tabular}}

Yu et al.: Synergistic Anti-EBV Effect of Mabs

size; Millipore, Darmstadt, Germany, Cat\#SLGP033RB). 293T cells cultured in 8-well Chamber Slides with removable wells were incubated with the DiI-labeled trVLPs at $4^{\circ} \mathrm{C}$ for $10 \mathrm{~min}$, washed with PBS, and then warmed to $37^{\circ} \mathrm{C}$. Then, 4',6-diamidino-2-phenylindole (DAPI, diluted by PBS in $10 \mu \mathrm{g} / \mathrm{ml}$, Invitrogen, Waltham, MA, USA, Cat\#P36931) was added to stain the nucleus. From 10 to $60 \mathrm{~min}$ at $37^{\circ} \mathrm{C}$, the well was set on the stage of a fluorescence microscope, and the internalization process of DiI-labeled trVLPs in 293T cells was imaged at different time points.

\section{Electron microscopy analysis of trVLPS}

Purified trVLPs $(10 \mu \mathrm{l})$ were pipetted on 300 mesh copper grid coated with carbon film and incubated for 5 minutes at room temperature. Grids were then washed with clear water and negatively stained for 15 seconds using $1 \%$ phosphotungstic acid buffered to $\mathrm{pH} 7.0$ with $1 \mathrm{M}$ ammonium hydroxide. The trVLPs were visualized using a Hitachi H7000 transmission electron microscope.

\section{Neutralization protocol of mAbs against trVLPS}

trVLPs (MOI=1.5) were added to 3, 5, 10, or $15 \mu \mathrm{g} / \mathrm{ml}$ GP-mAb or the three VP40-mAbs, mixed thoroughly in opti-MEM (Invitrogen, Waltham, MA, USA, Cat\#31985070), and incubated at room temperature for $1 \mathrm{~h}$. Then, the compound was added to the 293T cells in 24 -well plates $\left(1 \times 10^{5}\right.$ cells/well). Meanwhile, isotype antibody (IgG2a, Abcam, Cambridge, UK, Cat\#ab1281) with different concentrations were treated as negative control group. trVLPs (MOI=1.75) were added to the same concentrations of mAbs, and, following the same procedure, the compound was added to the cells in 6 -well plates $\left(4 \times 10^{5}\right.$ cells /well). Cells were harvested at 24, 48, and $72 \mathrm{~h}$ post treatment and trVLPs -RNA was quantified by qRT-PCR (cells in 24-well plates). TrVLPs -GP was detected by western blot analysis (cells in 6-well plates). trVLPs added to equivalent opti-MEM were set as positive control, normal 293T cells without trVPLs were treated as negative control.

RNA extraction and quantitative real-time reverse transcription polymerase chain reaction ( $q R T-P C R$ )

Total RNA was extracted from 293T cells in 24-well plates using TRIzol (Invitrogen, Waltham, MA, USA, Cat\#15596018) according to the manufacturer's instruction. qRT-PCR was performed with the ZEBOV nucleic acid test kit (Zhijiang bio-tech, Shanghai, China, Cat\#QR-0220-02), on the ABI 7500 qPCR system $\left(45^{\circ} \mathrm{C}\right.$ for $10 \mathrm{~min}, 95^{\circ} \mathrm{C}$ for $15 \mathrm{~min}$, one cycle; then, $95^{\circ} \mathrm{C}$ for $15 \mathrm{sec}, 60^{\circ} \mathrm{C}$ for $30 \mathrm{sec}, 45 \mathrm{cycles}$ ). The positive control, provided by the kit, was serially diluted over three orders of magnitude, and the absolute quantity of trVLPs RNA (copy/ml) was calculated with the Ct and standard curve. All qRT-PCR reactions were performed in triplicate and repeated three independent times.

\section{Immunofluorescence assay}

293T cells were cultured on 8-well LabTek II chamber slides (Thermo Scientific, Waltham, MA, USA, Cat\#177402PK) and infected with trVLPs (MOI = 1.5) for $72 \mathrm{~h}$. Then, cells were fixed in $4 \%$ formaldehyde, washed 3 times with PBS, and permeabilized with 0.5\%Triton X-100. Following another three times of PBS washes, cells were blocked in 3\% human serum albumin solution for $30 \mathrm{~min}$. The cells were then incubated with anti-EBOV monoclonal antibody $\left(100 \mu \mathrm{g} / \mathrm{ml}\right.$, Abcam, Cambridge, UK, Cat\#ab1924) overnight at $4^{\circ} \mathrm{C}$. Following three times of PBS washes, cells were incubated for $1 \mathrm{~h}$ at room temperature with Alexa Fluor 488-conjugated anti-human antibody (1:400, Invitrogen, Waltham, MA, USA, Cat\#A-10631). Cells were microscopically observed with an Image-Pro Plus image system using a GFP imaging cube. The isotype antibody (IgG2a, Abcam, Cambridge, UK, Cat\#ab1281) was used as negative control.

\section{Protein extraction and western blot analysis}

Total protein from p1-p5 293T cells was extracted with extraction buffer RIPA (Beyotime, Shanghai, China, Cat\#P0013K) with protease inhibitor PMSF (Solarbio, Beijing, China, Cat\#P6730). Protein levels were then quantified using the bicinchoninic acid (BCA) method (Sigma, Santa Clara, CA, USA, Cat\#BCA1$1 \mathrm{KT}$ ). Each lane was loaded with $40 \mu \mathrm{g}$ of protein, run on a $10 \% \mathrm{SDS}$-polyacrylamide gel, and transferred onto PVDF membranes (Millipore, Darmstadt, Germany, Cat\#K5HA3224L). The membranes were then incubated with mouse monoclonal antibody to ZEBOV GP $(10 \mu \mathrm{g} / \mathrm{ml}$, Abcam, Cat\#ab1918), or mouse monoclonal anti GAPDH (1:2000, Abcam, Cat\#ab8245) overnight at $4^{\circ} \mathrm{C}$. Following a wash with TBS/ Tween-20, the membranes were incubated for $1 \mathrm{~h}$ at room temperature with HRP-conjugated anti-mouse IgG (1:2000, cell signaling technology, Danvers, MA, USA, Cat\#7076S) , rinsed with TBS/Tween-20, and the 


\section{Cellular Physiology Cell Physiol Biochem 2018;50:1055-1067 \begin{tabular}{l|l|l} 
and Biochemistry Published online: 24 October 2018 & $\begin{array}{l}\text { (c) } 2018 \text { The Author(s). Published by S. Karger AG, Basel } \\
\text { www.karger.com/cpb }\end{array}$ \\
\hline
\end{tabular} \\ Yu et al.: Synergistic Anti-EBV Effect of Mabs}

proteins of interest were detected with the SuperSignal West Pico chemiluminescent substrate (Thermo Fisher, Waltham, MA, USA, Cat\#34580).

\section{Antibody variable domain sequencing analysis}

Total RNA was isolated from frozen hybridoma cell lysates (producing ZJB08-1, A2G7, G7A6, F1B4, respectively) in TRIzol (Invitrogen, Cat\#15596-026), then was reverse transcribed into cDNA using universal primers following the protocol of PrimeScript ${ }^{\mathrm{TM}}$ 1st Strand cDNA Synthesis Kit (Takara, Dalian, China, Ca\# 6110A). The antibody fragments of variable heavy chain and variable light chain were amplified according to the standard operating procedure of rapid amplification of cDNA ends. Then, amplified antibody fragments were cloned into standard cloning vectors separately. Colony PCR was performed to screen the clones with inserts of correct sizes. No less than five colonies with inserts of correct sizes were sequenced for each fragment.

\section{Statistical analysis}

The data in normal distribution are presented as the mean \pm standard deviation (SD). Two-tailed, paired t-test or unpaired t-test with Welch's correction was performed when appropriate. All analysis was performed by Graphpad Prism 5 (GraphPad Software, UK), and differences between group means with $\mathrm{P}<$ 0.05 were considered statistically significant.

\section{Results}

\section{Monoclonal antibodies}

We produced mAbs against Zaire EBOV GP and VP40, respectively. The anti-GP antibody, ZJEB8-01, targets GP RBD; the anti-VP40 antibody, A2G7, targets VP40 NTD; the anti-VP40 antibodies, G7A6, and F1B4, target VP40 CTD. The detailed information was summarized in Table 1.

Zaire EBOV-trVLP mimic authentic ebola virion both in morphology and basic function under biosafety level 2 conditions

Zaire EBOV-trVLPs were synthesized from passage 1 to 5 . Reporter activity was detected according to the protocol, and increased with each passage (Fig. 1A). The morphology of trVLPs was visualized with electron microscopy, appeared as filamentous-like structures (Fig. 1B). This demonstrated that trVLP could mimic the real ebola virion in a considerable degree. Internalization and tracking of DiI-labeled trVLPs in live 293T cells were also visualized by fluorescent microscopy (Fig. 1C). The images indicated that trVLPs translocated relatively in the cytoplasm over time.

\section{Monoclonal antibodies against GP or VP40 neutralize trVLPs}

To test the neutralization effect of the mAbs, trVLPs were incubated with 3, 5, 10, or 15 $\mu \mathrm{g} / \mathrm{ml}$ ZJEB8-01, A2G7, G7A6, or F1B4. trVLPs RNA was harvested at $48 \mathrm{~h}$ and checked by qRT-PCR (Fig. 2A-D). The data indicates that the effective dose of ZJEB8-01 was $5 \mu \mathrm{g} / \mathrm{ml}(\mathrm{P}$ $<0.05$ ), and that a dose $\geq 10 \mu \mathrm{g} / \mathrm{ml}$ achieved a significant effect $(\mathrm{P}<0.01$ ) (Fig. 2A). A2G7 was effective at $10 \mu \mathrm{g} / \mathrm{ml}$ or above $(\mathrm{P}<0.01)$ (Fig. 2B), G7A6 at $5 \mu \mathrm{g} / \mathrm{ml}(\mathrm{P}<0.05)$, with a very significant effect at $15 \mu \mathrm{g} / \mathrm{ml}(\mathrm{P}<0.01)$ (Fig. 2C). F1B4 was effective at $5 \mu \mathrm{g} / \mathrm{ml}(\mathrm{P}<$

Table 1. The targeted antigen sites of GP-mAb and VP40-mAbs

\begin{tabular}{|c|c|c|c|}
\hline mAbs & $\begin{array}{c}\text { Epitope } \\
\text { (amino acid sequence) }\end{array}$ & $\begin{array}{c}\text { Position } \\
\text { (amino acid location) }\end{array}$ & $\begin{array}{c}\text { Subclass } \\
\text { ( IgG, light chain) }\end{array}$ \\
\hline ZJEB8-01 & DNDSTASDTPPATTAAGPLK & RBD of GP & IgG1, $\mathrm{K}$ \\
\hline A2G7 & ARSNSTIARGGNSNC & NTD ofVP40 & IgG1,K \\
\hline G7A6 & CTGKKVTSKNGQPI & CTD of VP40 & $\operatorname{IgG1,\kappa }$ \\
\hline F1B4 & CHSPASLPAMVEK & CTD of VP40 & $\operatorname{IgG1,\kappa }$ \\
\hline
\end{tabular}




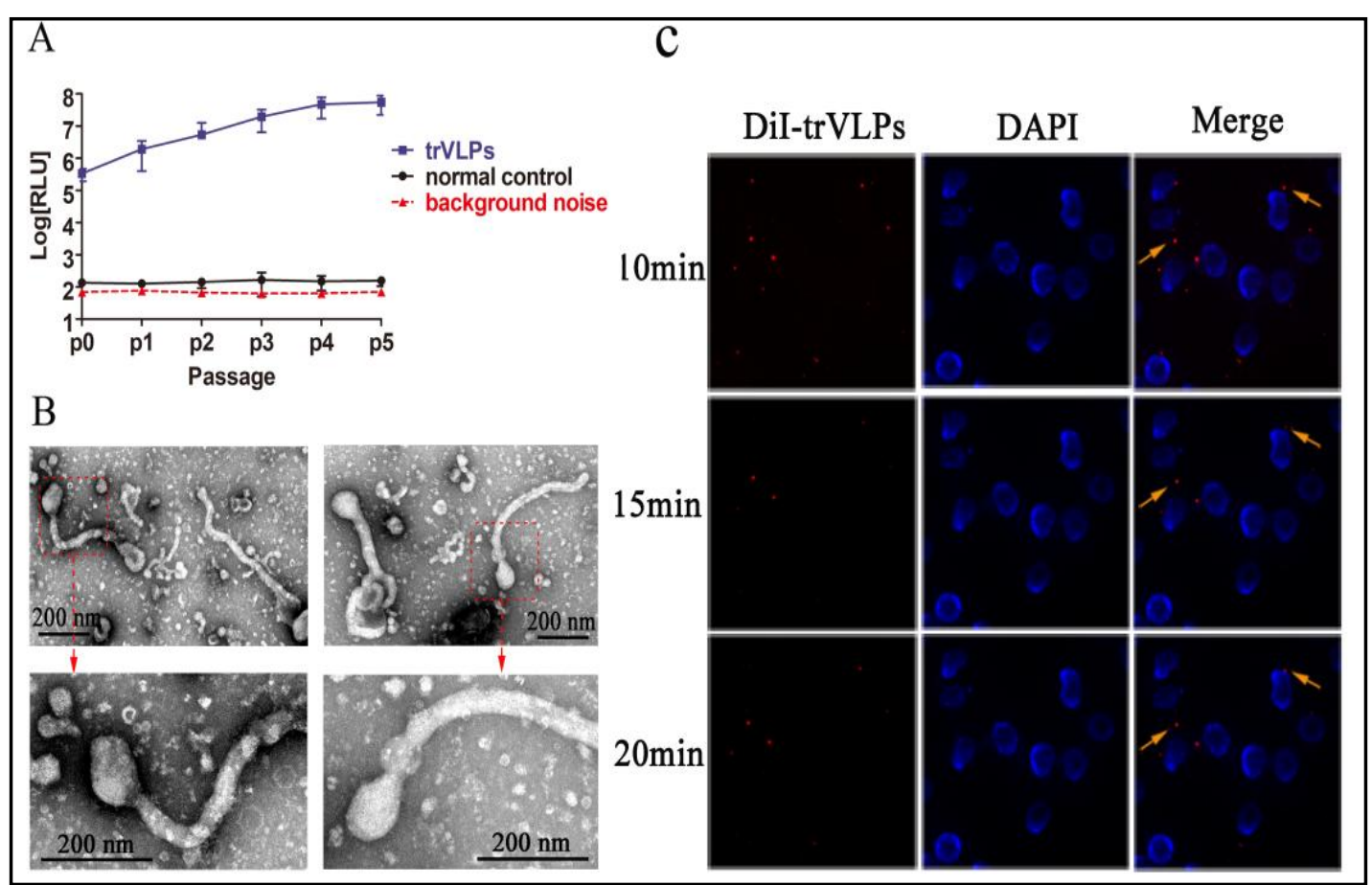

Fig. 1. Synthesis and identification of trVLPs. (A) The level of reporter activity in trVLPs assay. The reporter activity of trVLPs was measured over 5 passages. Untreated 293T cells were used as a negative control. The background noise of the luminometer is indicated as dashed line. Means and standard deviations of six biological replicates from three independent experiments were shown. RLU, relative luciferase unit. (B) trVLPs visualization with electron microscopy. trVLPs were produced and purified by ultracentrifugation over a $20 \%$ sucrose gradient. The particles were visualized using electron microscopy after negative staining, showed filamentous-like structures. (C) Internalization and tracing of DiI-labeled trVLPs in live 293T cells. 10, 15, and 20 minutes after infecting 293T cells, Dil-labeled trVLPs were traced by fluorescence microscopy (indicated by yellow arrows).

0.05 ) and highly significant at $10 \mu \mathrm{g} / \mathrm{ml}(\mathrm{P}<0.01)$ (Fig. 2D). Meanwhile, isotype antibody in different dose was treated as negative control (Fig. 2E). To confirm the neutralization effect, we verified the dose-response of each of the four mAbs at 5,10 , and $15 \mu \mathrm{g} / \mathrm{ml}$ by western blot. The expression of GP in cell lysate was used to evaluate the level of trVLP and neutralization efforts of the four mAbs. Normal 293T cells without trVLPs infection were set as contrast. Western blot results revealed that the expression of GP decrease with increasing concentrations of mAbs (Fig. 2F-I). This data revealed that these mAbs are effective in neutralizing the Zaire EBOV trVLPs. To further support this viewpoint, immunofluorescence was conducted on 293T cells infected by trVLPs which incubated with 5,10 , or $15 \mu \mathrm{g} / \mathrm{ml}$ ZJEB8-01, A2G7, G7A6, or F1B4. 293T cells infected with trVLPs, normal 293T cells without trVLPs were set as controls. Meanwhile, isotype antibody was treated as negative control. Results showed that with increasing mAbs dosage, the distribution density of GP decreased in the cells (Fig. 2J). These images data confirmed the neutralization efforts of the mAbs.

Monoclonal antibody cocktail of anti-GP and VP40, and cocktail of multiple anti-VP40$m A b s$ results in increased neutralization compared to single $m A b$ treatment

Following the confirmation of the neutralization effect of the antibodies, we tested the neutralization of 5,10 , and $15 \mu \mathrm{g} / \mathrm{ml} \mathrm{mAbs}$ at 24,48 , and $72 \mathrm{~h}$. To check the synergistic effect, mAbs cocktail of anti-GP and each of the anti-VP40, and a cocktail using the different antiVP40-mAbs (the dose of each $\mathrm{mAb}$ in each cocktail was $5 \mu \mathrm{g} / \mathrm{ml}$ ) were compared to the results of treatment with one $\mathrm{mAb}$ at $10 \mu \mathrm{g} / \mathrm{ml}$ alone (Fig. 3A-E). Results indicated that the neutralization effect of mAbs at $5 \mu \mathrm{g} / \mathrm{ml}$ had not significantly changed from $24 \mathrm{~h}$ to 72 


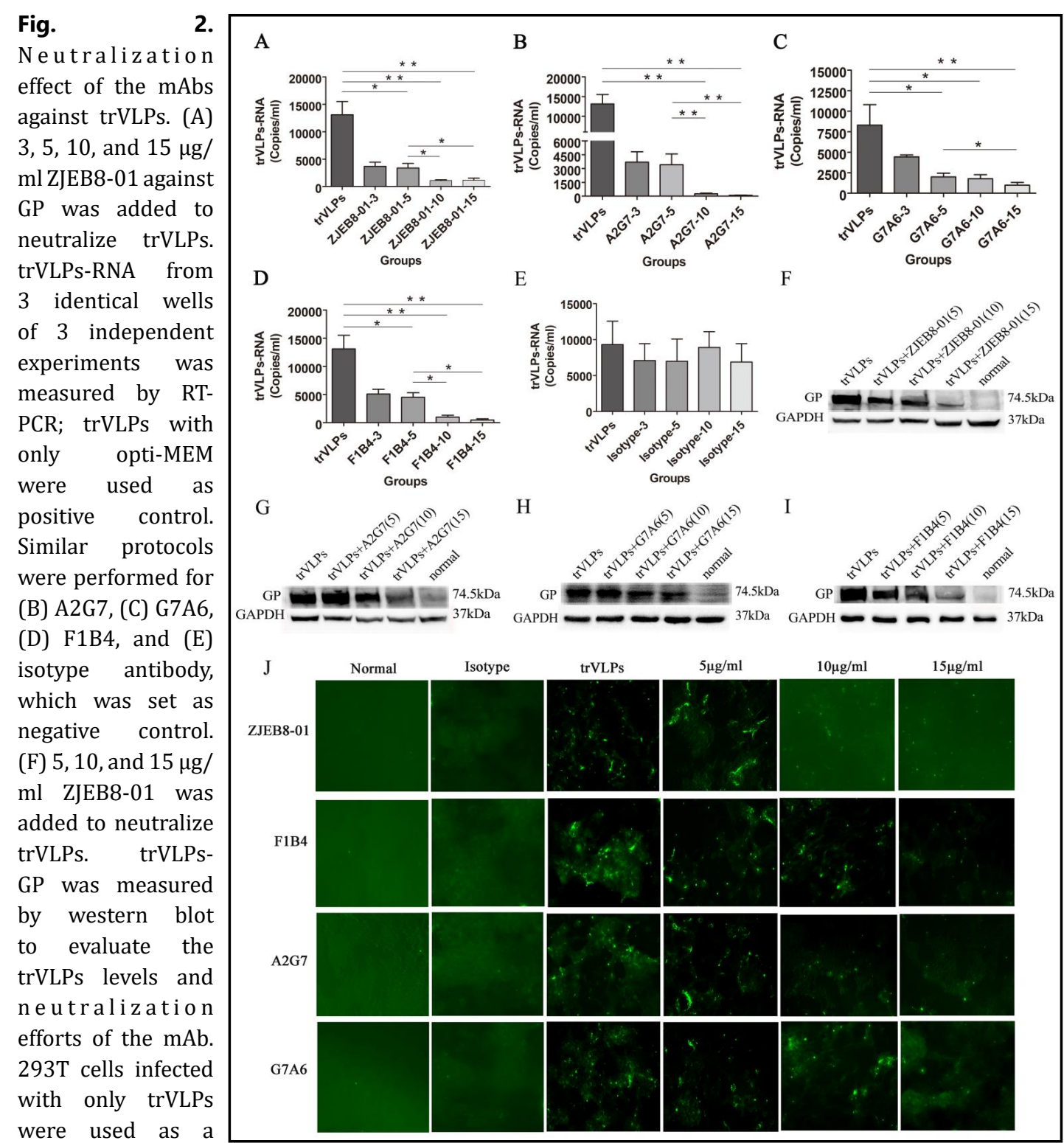

positive

and untreated 293T cells were used as a negative control. GAPDH was used as internal reference. Similar protocols were performed with (G) A2G7, (H) G7A6, and (I) F1B4. (J) Immunofluorescence assay of the neutralization effect. 5,10 , and $15 \mu \mathrm{g} / \mathrm{ml} \mathrm{mAbs}$ were incubated with infected cells. 293T cells treated with trVLPs only were used as positive control; the isotype antibody group and untreated normal 293T cells were used as negative controls. ${ }^{*}, \mathrm{P}<0.05 ;{ }^{*}, \mathrm{P}<0.01$.

h (Fig. 3A). Each mAbs, at $10 \mu \mathrm{g} / \mathrm{ml}$, had a significant neutralizing effect at $48 \mathrm{~h}$, with no significant difference at $72 \mathrm{~h}$. However, the mAbs cocktails of ZJEB8-01 $(5 \mu \mathrm{g} / \mathrm{ml})$ and each VP40-mAb (5 $\mu \mathrm{g} / \mathrm{ml})$ (ZJEB8-01+A2G7, ZJEB8-01+G7A6, ZJEB8-01+F1B4), and cocktails of two VP40-mAbs (each at $5 \mu \mathrm{g} / \mathrm{ml})(A 2 G 7+G 7 A 6, A 2 G 7+F 1 B 4$, G7A6+ F1B4) displayed better neutralization effects than a single $\mathrm{mAb}$ at $10 \mu \mathrm{g} / \mathrm{ml}$ (Fig. 3B). The $15 \mu \mathrm{g} / \mathrm{ml} \mathrm{mAbs}$ had strong neutralization effects compared to the trVLPs group, which did not change over the indicated time points (Fig. 3C). To confirm the neutralization effects of mAbs cocktail, we performed similar protocols and checked GP expression to evaluate the trVLP levels and neutralization efforts of the four mAbs by western blot. The results clearly demonstrated that GP expression in mAbs cocktail groups, ZJEB8-01 and each VP40-mAb, was reduced 


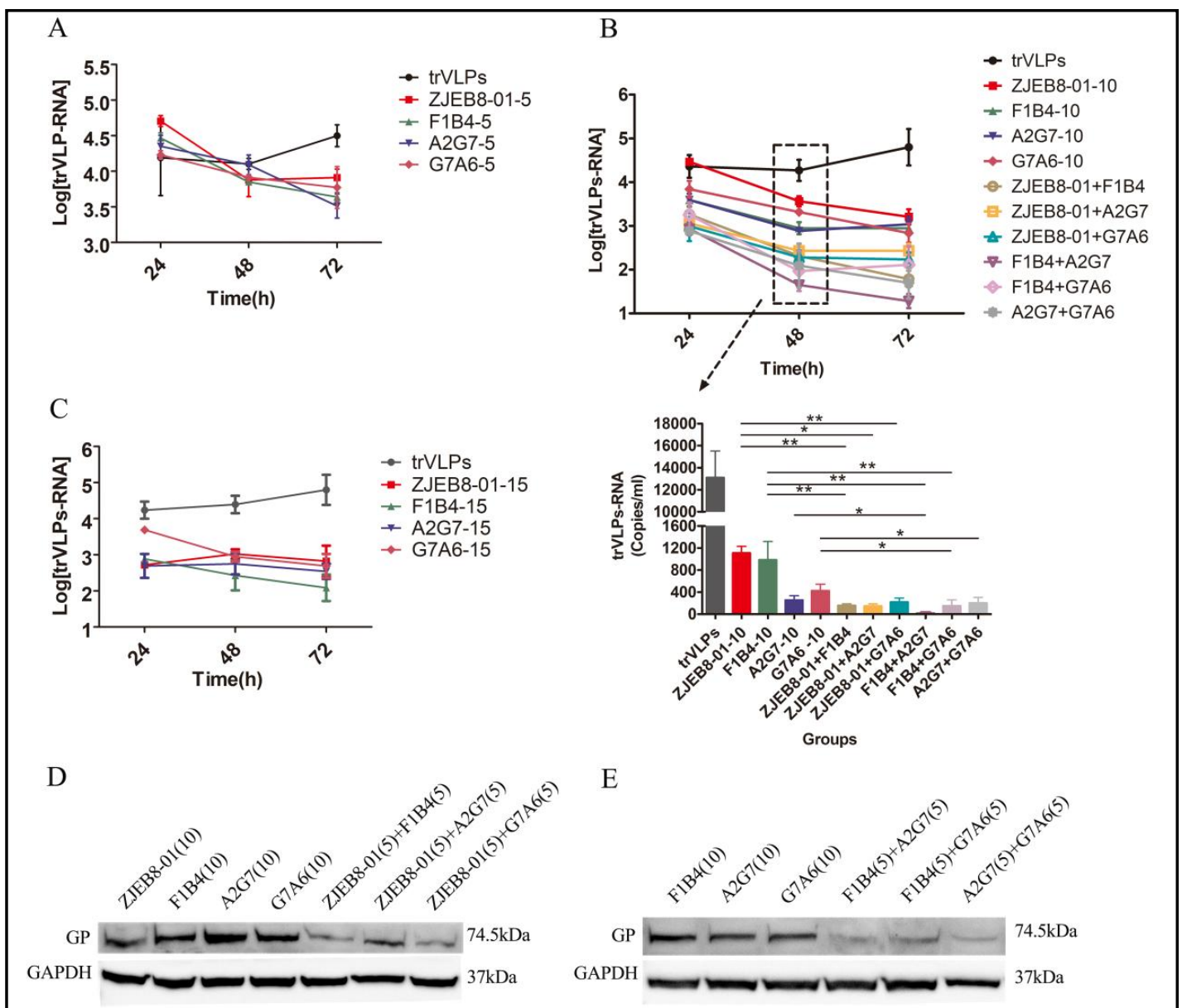

Fig. 3. Time dependent effect of mAbs cocktails on neutralization. (A) Neutralization effect of $5 \mu \mathrm{g} / \mathrm{ml} \mathrm{mAbs}$ does not significantly change over time. (B) $10 \mu \mathrm{g} / \mathrm{ml} \mathrm{mAbs} \mathrm{exhibits} \mathrm{strong} \mathrm{neutralizing} \mathrm{effect} \mathrm{at} 48$ and 72 $\mathrm{h}$, but not $24 \mathrm{~h}$. The mAbs cocktail of ZJEB8-01 (5 $\mu \mathrm{g} / \mathrm{ml})$ and each VP40-mAb (5 $\mu \mathrm{g} / \mathrm{ml})(\mathrm{ZJEB} 8-01+\mathrm{A} 2 \mathrm{G} 7$, ZJEB8-01+G7A6, ZJEB8-01+F1B4), and cocktail of two VP40-mAbs (each at $5 \mu \mathrm{g} / \mathrm{ml}$ ) (A2G7+G7A6, A2G7+ F1B4, G7A6+ F1B4) displayed better neutralization effects than a single mAb at $10 \mu \mathrm{g} / \mathrm{ml}$. (C) $15 \mu \mathrm{g} / \mathrm{ml}$ mAbs had significant neutralization effects compared with the trVLPs group, but didn't increase over time. (D) Western blot analysis of neutralization effects of ZJEB8-01 (5 $\mu \mathrm{g} / \mathrm{ml})$ and VP40-mAb (5 $\mu \mathrm{g} / \mathrm{ml})$ cocktail. GP was checked to evaluate the trVLPs levels and neutralization efforts of the cocktail. Treatment with single $\mathrm{mAb}$ at $10 \mu \mathrm{g} / \mathrm{ml}$ was used as control. (E) Western blot analysis of neutralization effects of VP40-mAbs (each at $5 \mu \mathrm{g} / \mathrm{ml}$ ) cocktails. GP was checked to access the trVLPs levels and neutralization efforts of the cocktails. Single $\mathrm{mAb}$ at $10 \mu \mathrm{g} / \mathrm{ml}$ was used as control. *, $\mathrm{P}<0.05$; **, $\mathrm{P}<0.01$.

significantly compared to single-mAb groups (Fig. 3D). Furthermore, the GP expression in cocktail groups of two VP40-mAbs is significantly lower than in single-mAb groups (Fig. 3E).

\section{Sequencing analysis of GP-mAb and VP40-mAbs}

After identifying the antiviral effect of the above antibodies, we checked the detailed DNA sequences (data are not shown) and amino acid sequences of the four mAbs (Fig. 4A, 4C, 4E, 4G). The data reveals the heavy and light DNA chains and amino acid sequences for each $\mathrm{mAb}$. Based on the idea of homology modeling, we verified the simulated 3-D structure of the mAbs via SWISS-MODEL software (Fig. 4B, 4D, 4F, 4H). Those pictures showed that variable regions of both heavy chain and light chain are formed by the folding of different numbers of anti-parallel $\beta$ sheets, and the hydrophobic amino acids could form an antigen binding groove (indicated by black arrows).

\section{KARGER}


Fig. 4. The detailed amino acid sequence and simulated 3-D structures of the four mAbs. (A) The heavy and light chain amino acid sequence of ZJEB8-01, and (B) the simulated 3-D structure of ZJEB8-01. (C) The heavy and light chain amino acid sequence of A2G7, and (D) its simulated 3-D structure. (E) The heavy and light chain amino acid sequence of G7A6, and $(F)$ its simulated 3-D structure. (G) The heavy and light chain amino acid sequence of F1B4, and (H) its simulated 3-D structure. In (B), (D), (F) and (H), the black arrows indicate the possible antigen binding grooves. V: heavy chain; L, light chain.
A

ZJEB8-01

Heavy chain: Amino acids sequence (133 AA)

Leader sequence-FR $1 \cdot \mathrm{CDR} 1 \cdot \mathrm{FR} 2-\mathrm{CDR} 2-\mathrm{FR} 3 \cdot \mathrm{CDR} 3 \cdot \mathrm{FR} 4$

MAWVWTLLFLMPAAQSFQAQIQLVQSGPELKKPGETVKISCKASGYTFTDYS

IHWVKQAPGKGLKWGGINTETGEPTYTDDFKGRFAFSLETSASTAFLQIKNL

KNEDMATYFCAPNFFVYWGQGTLTVSA

Light chain: Amino acids sequence (132 AA)

Leader sequence-FR1-CDR1-FR2-CDR2-FR3-CDR3-FR4

MMSPAQFLFLLVLWIREANGDVVMTQTPLTLSVIIGQTASISCKSSQSLLDSN

GKTHVNTVLLQRPGQSPKRLIYLVSKLDSGVPDRFTGSGSGTDFTLKISRVEAE

DLGVYYCWQGTHFPQTFGGGTLEIK

C

\section{A2G7}

Heavy chain: Amino acids sequence (139 AA)

Leader sequence-FR1-CDR1-FR2-CDR2-FR3-CDR3-FR4

MGWSYIILFLVATVTDVHSQVQLQQPGAEFVKPGASVKLSCKASGYTFTSYW MHWVKQRPGQGLEWIGEINPRDGVTNYSAKFKSKATLTVDKSSSTAYMHLS

SLTSDDSAVYYCTTYYSDWDYAMDSWGQGTSVTVSS

Light chain: Amino acids sequence (132 AA)

Leader sequence-FR1-CDR1-FR2-CDR2-FR3-CDR3-FR4

MMSPAQFLFLLVLWIRETNGDVVMTQTPLTLSVTIGQPASISCKSSQSLLYSD GNTYLNWFLQRPGQSPKRLIYLVSKLDSGVPDRFTGSGSGTDFTLKISRVEAE DLGVYYCWQGTHFPLTFGTGTKLELK

$\mathbf{E}$

G7A6

Heary chain: Amino acids sequence (131 AA)

Leader sequence-FR1-CDR1-FR2-CDR2-FR3-CDR3-FR4

MDRLTSSFLLLIVPAYVLSQVTLKESGPGILQPSQTLSLTCSFSGFSLSTSGMGV

SWVRQPSGKGLEWLAHIYWDDDKRINPSLKSRLTISKDTSRNQVFLKITSVD

TADTATYYCAQGGYWGQGTSTVSS

Light chain: Amino acids seq̨uence (138 AA)

Leader sequence-FR1-CDR1-FR2-CDR2-FR3-CDR3-FR4

MESNTLLLWVLLLWVPGSTGDIVLTQSPASLAVSLGQKATISCKASKKVTIFG

SISALHWYQQKPGQPPKLIYNGAKLESGVSARFSDSGSQNRSPFGNQLSFTLTI

DPVEADDAATYYCLQTNEVPTFGGGTKLEIK

G

F1B4

Heavy chain: Amino acids sequence (135 AA)

Leader sequence-FR1-CDR1-FR2-CDR2-FR3-CDR3-FR4

MGWSWIFLFLLSGTAGVLSEVRLQQSGPELGKPGASVKISCKTSGYVFIEYTI

HWMKQSHGKSLEWIGNIYPKNGGTAYSQKFKGRATLSADKSSRTAYTELRSL

TSEDSAVYYCARDNYGFDCWGQGTTLTVSS

Light chain: Amino acids sequence (132 AA)

Leader sequence-FR1-CDR1-FR2-CDR2-FR3-CDR3-FR4

MMSPAQFLFLLVLWIQETNGDDVMTQTPLTLSVTIGQPASISCKSSQTLLYSD

GKTYLSWLLQRPGQSPKRLIYLVSKLDSGVPDRFTGSGSGTDFTLKIGRVEAE

DLGVYFCVQGTHFPHTFGAGTKLELK
B

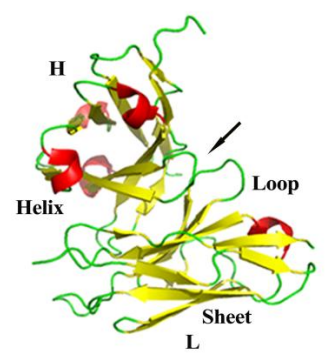

D

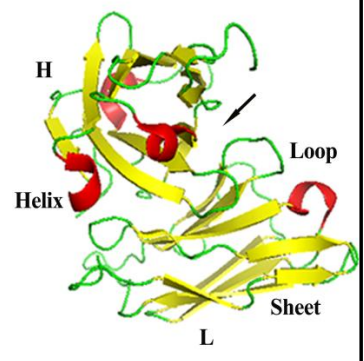

$\mathbf{F}$

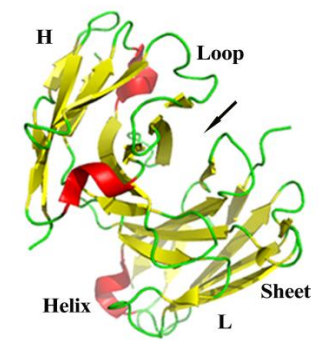

H

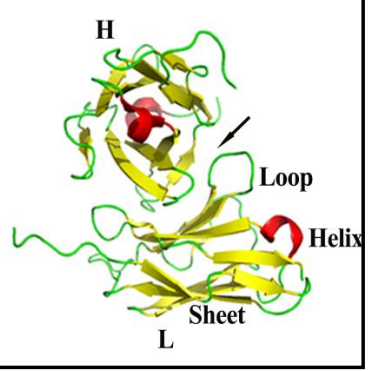

\section{Discussion}

Despite the recent outbreak of the largest EVD in West Africa from December 2013 to March 2016, no vaccines or treatment for EBOV has been approved to date. Currently, The EVD epidemic expedited several promising therapeutics for clinical assessment: (1) small molecule inhibitors, such as BCX4430, GS-5734, AVI-6002, and favipiravir, have been evaluated for the effectiveness against EBOV infection in animal models or in nonrandomized clinical trials [23-26]; (2) immune-based therapeutics, including IFNs, plasma transfusion, and mAbs from recovered EVD patients, are evaluated in clinical studies [27-31]. 


\section{Cellular Physiology Cell Physiol Biochem 2018;50:1055-1067 and Biochemistry \begin{tabular}{l|l} 
DOI: 10.1159/000494530 & $\begin{array}{l}\text { C } 2018 \text { The Author(s). Published by S. Karger AG, Basel } \\
\text { www.karger.com/cpb }\end{array}$
\end{tabular}

MAbs are currently one of the most promising treatment options against EVD, which have been confirmed by studies of consistently higher rates of survival in lethally challenged non-human primates. However, limited but promising therapeutic evidence is available in humans [5, 32]. Up to now, over $500 \mathrm{mAbs}$ against EBOV have been extracted from recovered patients $[15,17,33,34]$ or developed from animal models [35, 36]; however, most of those mAbs have not been checked in clinical trials. To date, about 20 kinds of EBOV mAbs have been identified and characterized, several of them were found promising in non-human primate models, such as mAb114, MIL77E, MB-003, ZMab, and ZMapp ${ }^{\mathrm{TM}}[5,6]$.

Combinations of two or more antibodies probably have synergistic protection by complementary mechanisms, including neutralization-dependent and neutralizationindependent mechanisms. For example, in the ZMAb cocktail, c4G7 and c2G4 are neutralizing, whereas $\mathrm{c} 1 \mathrm{H} 3$ is non-neutralizing [37]. In MB-003 cocktail, none mAbs are neutralizing [38]. However, both ZMAb and MB-003 mixtures are protective [39]. It's presumed that nonneutralizing antibodies might confer protection in vivo by preventing budding of nascent virions, which has been confirmed at experiment of inhibition of Marburg virus budding by non-neutralizing antibodies [40].

Currently, the antiviral therapeutics of mAb-cocktail are limited to anti-GP antibodies, such as ZMAb cocktail, MB-003, and ZMapp ${ }^{\mathrm{TM}}$, while antiviral therapeutics targeting VP40 still underway. As mentioned above, VP40 plays a crucial role in membrane binding, dimerization, oligomerization, make it a promising therapeutic target. Therefore, we synthesized anti-Zaire EBOV GP and VP40 monoclonal antibodies, and characterized the neutralizing effect of anti-GP and VP40 mAbs in vitro. The results suggest that anti-GP or antiVP40 mAbs effectively inhibit ZEBOV-trVLPs replication in vitro. Furthermore, the cocktail of anti-GP and each anti-VP40 mAb, or cocktail of each two anti-VP40 mAbs has a synergistic anti-viral effect. As demonstrated in this report, anti-GP mAb was designed to target the RBD of GP protein and supposed to inhibit virion entry; F1B4 and G7A6 were designed to target the CTD of VP40, which presumed to interrupt the membrane binding and oligomerization process; A2G7 targets the NTD of VP40, which likely to regulate dimerization and receptor signal transduction. As all four mAbs are IgG1 antibodies, they likely bound to the trVLPs extracellularly and interfered with virus attachment to the cell surface, suppressed membrane fusion and macropinocytosis to prevent virion entry. The viruses budding from the cell surface would then be neutralized by mAbs prior to the next infection. ADCC and complement reaction also has been shown to be induced by anti-GP antibodies [37, 39]. Thus, it's presumably the cocktails of anti-GP and anti-VP40 mAbs neutralize ZEBOV-trVLPs through different simultaneous mechanisms.

Meanwhile, comparing the effective dose of mAbs in our study to other authenticated mAbs is an interesting thing. Our results show that each mAb agaist trVLPs (MOI $=1.5$ ) in vitro is among $5-10 \mu \mathrm{g} / \mathrm{ml}$ (about $80 \%$ neutralization effort), cocktail could reduce the amount of mAbs and achieve better results (greater than $90 \%$ neutralization effort). ZMAb (mAb-cocktail of 2G4, 4G7, and 1H3), was estimated at 50\% neutralization effort of $0.139 \mu \mathrm{g} /$ $\mathrm{ml}$ in $2 \mathrm{G} 4, \quad 0.135 \mu \mathrm{g} / \mathrm{ml}$ in $4 \mathrm{G} 7$, and $27.6 \mu \mathrm{g} / \mathrm{ml}$ in $1 \mathrm{H} 3$ [37]. MAb114, achieved half-maximal effective concentration (EC50) at $0.02 \mu \mathrm{g} / \mathrm{ml}$, and mediated ADCC with maximal activity observed at concentration of $0.03 \mu \mathrm{g} / \mathrm{ml}$ [7]. ZMapp ${ }^{\mathrm{TM}}$ (mAb-cocktail of 2G4, 4G7, and 13C6), got EC50 at concentration $<0.1 \mu \mathrm{g} / \mathrm{ml}$ in $2 \mathrm{G} 4,0.1 \mu \mathrm{g} / \mathrm{ml}$ in $4 \mathrm{G} 7$, and $1 \mu \mathrm{g} / \mathrm{ml}$ in $13 \mathrm{C} 6$ [5, 41]. These data indicated low doses in antibodies cocktail at EC50. Although the dose of mAbs we developed got relatively high concentration in neutralization effort, it's still worthy of further research in the exact binding epitopes of those antibodies, and anti-virus study in vivo.

This work provides an analysis of anti-virus effects of anti-Zaire EBOV GP and VP40 mAbs. Our data suggest that the anti-GP or anti-VP40 mAbs neutralize Zaire EBOV trVLPs in vitro. Furthermore, a cocktail of anti-GP and anti-VP40 mAb, or of two anti-VP40 mAbs has a synergistic anti-virus effect. This is the first account to report important anti-viral effects of anti-GP and anti-VP40 mAbs cocktail in vitro. This information proves valuable for investigators developing further research in primate models. 


\section{Cellular Physiology Cell Physiol Biochem 2018;50:1055-1067 \begin{tabular}{ll|l} 
and Biochemistry & DOl: 10.1159/000494530 & $\begin{array}{l}\text { (c) } 2018 \text { The Author(s). Published by S. Karger AG, Basel } \\
\text { www.karger.com/cpb }\end{array}$
\end{tabular}}

Yu et al.: Synergistic Anti-EBV Effect of Mabs

\section{Acknowledgements}

This work was supported by the Major Program of National Natural Science Foundation of China [grant number 81590763].

\section{Disclosure Statement}

The authors have no conflicts of interest to declare.

\section{References}

1 Johnson KM, Lange JV, Webb PA, Murphy FA: Isolation and partial characterisation of a new virus causing acute haemorrhagic fever in Zaire. Lancet 1977;1:569-571.

- Kuhn JH, Becker S, Ebihara H, Geisbert TW, Johnson KM, Kawaoka Y, Lipkin WI, Negredo AI, Netesov SV, Nichol ST, Palacios G, Peters CJ, Tenorio A, Volchkov VE, Jahrling PB: Proposal for a revised taxonomy of the family Filoviridae: classification, names of taxa and viruses, and virus abbreviations. Arch Virol 2010;155:2083-2103.

3 Agua-Agum J, Ariyarajah A, Blake IM, Cori A, Donnelly CA, Dorigatti I, Dye C, Eckmanns T, Ferguson NM, Fraser C, Garske T, Hinsley W, Jombart T, Mills HL, Nedjati-Gilani G, Newton E, Nouvellet P, Perkins D, Riley S, Schumacher D et al.: Ebola Virus Disease among Male and Female Persons in West Africa. N Engl J Med 2016;374:96-98.

-4 Ajisegiri WS, Chughtai AA, MacIntyre CR: A Risk Analysis Approach to Prioritizing Epidemics: Ebola Virus Disease in West Africa as a Case Study. Risk Anal 2018;38:429-441.

-5 Qiu X, Wong G, Audet J, Bello A, Fernando L, Alimonti JB, Fausther-Bovendo H, Wei H, Aviles J, Hiatt E, Johnson A, Morton J, Swope K, Bohorov O, Bohorova N, Goodman C, Kim D, Pauly MH, Velasco J, Pettitt J et al.: Reversion of advanced Ebola virus disease in nonhuman primates with ZMapp. Nature 2014;514:47-53. Davidson E, Bryan C, Fong RH, Barnes T, Pfaff JM, Mabila M, Rucker JB, Doranz BJ: Mechanism of Binding to Ebola Virus Glycoprotein by the ZMapp, ZMAb, and MB-003 Cocktail Antibodies. J Virol 2015;89:1098210992.

7 Corti D, Misasi J, Mulangu S, Stanley DA, Kanekiyo M, Wollen S, Ploquin A, Doria-Rose NA, Staupe RP, Bailey M, Shi W, Choe M, Marcus H, Thompson EA, Cagigi A, Silacci C, Fernandez-Rodriguez B, Perez L, Sallusto F, Vanzetta F et al.: Protective monotherapy against lethal Ebola virus infection by a potently neutralizing antibody. Science 2016;351:1339-1342.

-8 Chan SY, Empig CJ, Welte FJ, Speck RF, Schmaljohn A, Kreisberg JF, Goldsmith MA: Folate receptor-alpha is a cofactor for cellular entry by Marburg and Ebola viruses. Cell 2001;106:117-126.

-9 Kuhn JH, Radoshitzky SR, Guth AC, Warfield KL, Li W, Vincent MJ, Towner JS, Nichol ST, Bavari S, Choe H, Aman MJ, Farzan M: Conserved receptor-binding domains of Lake Victoria marburgvirus and Zaire ebolavirus bind a common receptor. J Biol Chem 2006;281:15951-15958.

10 Nanbo A, Imai M, Watanabe S, Noda T, Takahashi K, Neumann G, Halfmann P, Kawaoka Y: Ebolavirus is internalized into host cells via macropinocytosis in a viral glycoprotein-dependent manner. PLoS Pathog 2010;6:e1001121.

11 Olejnik J, Ryabchikova E, Corley RB, Muhlberger E: Intracellular events and cell fate in filovirus infection. Viruses 2011;3:1501-1531.

12 Takada A: Filovirus tropism: cellular molecules for viral entry. Front Microbiol 2012;3:34.

13 Adu-Gyamfi E, Soni SP, Xue Y, Digman MA, Gratton E, Stahelin RV: The Ebola virus matrix protein penetrates into the plasma membrane: a key step in viral protein 40 (VP40) oligomerization and viral egress. J Biol Chem 2013;288:5779-5789.

14 Stahelin RV: Could the Ebola virus matrix protein VP40 be a drug target? Expert Opin Ther Targets 2014;18:115-120.

15 Bornholdt ZA, Turner HL, Murin CD, Li W, Sok D, Souders CA, Piper AE, Goff A, Shamblin JD, Wollen SE, Sprague TR, Fusco ML, Pommert KB, Cavacini LA, Smith HL et al.: Isolation of potent neutralizing antibodies from a survivor of the 2014 Ebola virus outbreak. Science 2016;351:1078-1083. 


\section{Cellular Physiology Cell Physiol Biochem 2018;50:1055-1067

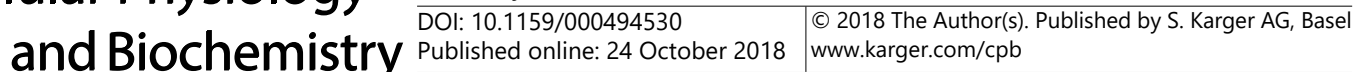

Yu et al.: Synergistic Anti-EBV Effect of Mabs

16 Balmith M, Soliman ME: VP40 of the Ebola Virus as a Target for EboV Therapy: Comprehensive Conformational and Inhibitor Binding Landscape from Accelerated Molecular Dynamics. Cell Biochem Biophys 2017;75:65-78.

17 Qiu X, Alimonti JB, Melito PL, Fernando L, Stroher U, Jones SM: Characterization of Zaire ebolavirus glycoprotein-specific monoclonal antibodies. Clin Immunol 2011;141:218-227.

18 Castilho A, Bohorova N, Grass J, Bohorov O, Zeitlin L, Whaley K, Altmann F, Steinkellner H: Rapid high yield production of different glycoforms of Ebola virus monoclonal antibody. PloS one 2011;6:e26040.

19 Trier NH, Mortensen A, Schiolborg A, Friis T: Production and Screening of Monoclonal Peptide Antibodies. Methods Mol Biol 2015;1348:109-126.

20 Holzlohner P, Hanack K: Generation of Murine Monoclonal Antibodies by Hybridoma Technology. J Vis Exp : JoVE 2017.

-21 Hoenen T, Groseth A, de Kok-Mercado F, Kuhn JH, Wahl-Jensen V: Minigenomes, transcription and replication competent virus-like particles and beyond: reverse genetics systems for filoviruses and other negative stranded hemorrhagic fever viruses. Antiviral Res 2011;91:195-208.

-22 Hoenen T, Watt A, Mora A, Feldmann H: Modeling the lifecycle of Ebola virus under biosafety level 2 conditions with virus-like particles containing tetracistronic minigenomes. J Vis Exp : JoVE 2014:52381.

23 Fabozzi G, Nabel CS, Dolan MA, Sullivan NJ: Ebolavirus proteins suppress the effects of small interfering RNA by direct interaction with the mammalian RNA interference pathway. J Virol 2011;85:2512-2523.

-24 Oestereich L, Rieger T, Neumann M, Bernreuther C, Lehmann M, Krasemann S, Wurr S, Emmerich P, de Lamballerie X, Olschlager S, Gunther S: Evaluation of antiviral efficacy of ribavirin, arbidol, and T-705 (favipiravir) in a mouse model for Crimean-Congo hemorrhagic fever. PLoS Negl Trop Dis 2014;8:e2804.

25 Wolf T, Kann G, Becker S, Stephan C, Brodt HR, de Leuw P, Grunewald T, Vogl T, Kempf VA, Keppler OT, Zacharowski K: Severe Ebola virus disease with vascular leakage and multiorgan failure: treatment of a patient in intensive care. Lancet 2015;385:1428-1435.

-26 Sissoko D, Laouenan C, Folkesson E, M'Lebing AB, Beavogui AH, Baize S, Camara AM, Maes P, Shepherd S, Danel C, Carazo S, Conde MN, Gala JL, Colin G, Savini H, Bore JA, Le Marcis F, Koundouno FR, Petitjean F, Lamah MC et al.: Experimental Treatment with Favipiravir for Ebola Virus Disease (the JIKI Trial): A Historically Controlled, Single-Arm Proof-of-Concept Trial in Guinea. PLoS Med 2016;13:e1001967.

27 Richardson JS, Wong G, Pillet S, Schindle S, Ennis J, Turner J, Strong JE, Kobinger GP: Evaluation of Different Strategies for Post-Exposure Treatment of Ebola Virus Infection in Rodents. J Bioterror Biodef 2011;0:007.

28 Qiu X, Wong G, Fernando L, Audet J, Bello A, Strong J, Alimonti JB, Kobinger GP: mAbs and Ad-vectored IFNalpha therapy rescue Ebola-infected nonhuman primates when administered after the detection of viremia and symptoms. Sci Transl Med 2013;5:207ra143.

29 Qiu X, Wong G, Fernando L, Ennis J, Turner JD, Alimonti JB, Yao X, Kobinger GP: Monoclonal antibodies combined with adenovirus-vectored interferon significantly extend the treatment window in Ebola virusinfected guinea pigs. J Virol 2013;87:7754-7757.

-30 Smith LM, Hensley LE, Geisbert TW, Johnson J, Stossel A, Honko A, Yen JY, Geisbert J, Paragas J, Fritz E, Olinger G, Young HA, Rubins KH, Karp CL: Interferon-beta therapy prolongs survival in rhesus macaque models of Ebola and Marburg hemorrhagic fever. J Infect Dis 2013;208:310-318.

-31 Rhein BA, Powers LS, Rogers K, Anantpadma M, Singh BK, Sakurai Y, Bair T, Miller-Hunt C, Sinn P, Davey RA, Monick MM, Maury W: Interferon-gamma Inhibits Ebola Virus Infection. PLoS Pathog 2015;11:e1005263.

-32 Wong G, Qiu X, Olinger GG, Kobinger GP: Post-exposure therapy of filovirus infections. Trends Microbiol 2014;22:456-463.

-33 Flyak AI, Shen X, Murin CD, Turner HL, David JA, Fusco ML, Lampley R, Kose N, Ilinykh PA, Kuzmina N, Branchizio A, King H, Brown L, Bryan C, Davidson E, Doranz BJ, Slaughter JC, Sapparapu G, Klages C, Ksiazek TG et al.: Cross-Reactive and Potent Neutralizing Antibody Responses in Human Survivors of Natural Ebolavirus Infection. Cell 2016;164:392-405.

34 Wec AZ, Herbert AS, Murin CD, Nyakatura EK, Abelson DM, Fels JM, He S, James RM, de La Vega MA, Zhu W, Bakken RR, Goodwin E, Turner HL, Jangra RK, Zeitlin L, Qiu X, Lai JR, Walker LM, Ward AB, Dye JM et al.: Antibodies from a Human Survivor Define Sites of Vulnerability for Broad Protection against Ebolaviruses. Cell 2017;169:878-890.e815. 


\section{Cellular Physiology Cell Physiol Biochem 2018;50:1055-1067

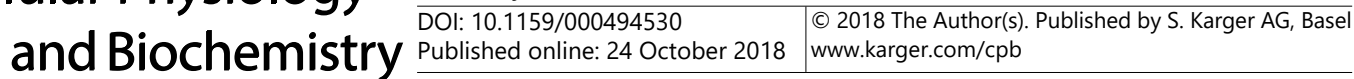 \\ Yu et al.: Synergistic Anti-EBV Effect of Mabs}

-35 Keck ZY, Enterlein SG, Howell KA, Vu H, Shulenin S, Warfield KL, Froude JW, Araghi N, Douglas R, Biggins J, Lear-Rooney CM, Wirchnianski AS, Lau P, Wang Y, Herbert AS, Dye JM, Glass PJ, Holtsberg FW, Foung SK, Aman MJ: Macaque Monoclonal Antibodies Targeting Novel Conserved Epitopes within Filovirus Glycoprotein. J Virol 2016;90:279-291.

>36 Zhao X, Howell KA, He S, Brannan JM, Wec AZ, Davidson E, Turner HL, Chiang CI, Lei L, Fels JM, Vu H, Shulenin S, Turonis AN, Kuehne AI, Liu G, Ta M, Wang Y, Sundling C, Xiao Y, Spence JS et al.: ImmunizationElicited Broadly Protective Antibody Reveals Ebolavirus Fusion Loop as a Site of Vulnerability. Cell 2017;169:891-904.e815.

37 Audet J, Wong G, Wang H, Lu G, Gao GF, Kobinger G, Qiu X: Molecular characterization of the monoclonal antibodies composing ZMAb: a protective cocktail against Ebola virus. Sci Rep 2014;4:6881.

38 Olinger GG Jr., Pettitt J, Kim D, Working C, Bohorov O, Bratcher B, Hiatt E, Hume SD, Johnson AK, Morton J, Pauly M, Whaley KJ, Lear CM, Biggins JE, Scully C, Hensley L, Zeitlin L: Delayed treatment of Ebola virus infection with plant-derived monoclonal antibodies provides protection in rhesus macaques. Proc Natl Acad Sci U S A 2012;109:18030-18035.

-39 Murin CD, Fusco ML, Bornholdt ZA, Qiu X, Olinger GG, Zeitlin L, Kobinger GP, Ward AB, Saphire EO: Structures of protective antibodies reveal sites of vulnerability on Ebola virus. Proc Natl Acad Sci U S A 2014;111:17182-17187.

40 Kajihara M, Marzi A, Nakayama E, Noda T, Kuroda M, Manzoor R, Matsuno K, Feldmann H, Yoshida R, Kawaoka Y, Takada A: Inhibition of Marburg virus budding by nonneutralizing antibodies to the envelope glycoprotein. J Virol 2012;86:13467-13474.

41 Mi Y, Yu M, Zhang L, Sun C, Wei B, Ding W, Zhu Y, Tang J, Xia G, Zhu L: COPB2 Is Upregulated in Prostate Cancer and Regulates PC-3 Cell Proliferation, Cell Cycle, and Apoptosis. Arch Med Res 2016;47:411-418. 